\title{
KIRÁLY RICHÁRD
}

\section{A 2015-ös siófoki idegenforgalmi szezon rendészeti tapasztalatai}

A 2015-ös esztendő a szállodák és a vendéglátósok által vágyott nyarat hozott a Balatonra, ez azonban a helyi rendőri szerveknek igazi próbatétel.

2015 nyarán sorra dőltek meg a hőségrekordok, az országos tiszti főorvos által elrendelt hőségriadó-terminusok hossza (hatszor rendeltek el hőségriadót, és még szeptemberre is áthúzódott), ezzel együtt nyolc-tíz éves rekordot döntött az idelátogatók és a szálláshelyeken értékesített vendégéjszakák száma.

2014-ben egész évben Siófokon és a kapcsolódó partszakaszokon majd egymillió volt az eladott vendégéjszakák száma, míg 2015-ben már az első nyolc hónapban meghaladta a kilencszázezret.

A következőkben összefoglalom a 2015. nyári idegenforgalmi szezon föbb rendészeti feladatait és tapasztalatait.*

Az ORFK vonatkozó 46/2013. utasítása az idegenforgalmi föszezont a június 1 . és augusztus 31 . közötti időszakra jelöli.

2015-ben is a májusi pünkösdi hétvégével kezdödött egy olyan idöszak, amikor a hétvégék már igen nagy forgalmúak, megtelnek a strandok és szórakozóhelyek, így ezek a hétvégi napok már több feladatot adnak a rendészetnek. Az iskolai vakáció kezdetén pedig - június közepétől - valóban megtelt a Balaton.

2015-ben is már a szezon kezdete előtt felvettük a kapcsolatot a Siófokon müködő jelentősebb szállodák és vendéglátóegységek vezetőivel. A cél az volt, hogy megosszuk egymással az előző években szerzett tapasztalatainkat a turisták számáról, jellemző szálláshelyeiről, és az általuk tanúsított magatartásokról. A vendégek kárára és általuk elkövetett szabályellenes magatartások megelőzése, valamint a már elkövetett jogellenes cselekmények tetteseinek mind hatékonyabb felderítése, az eljárás gyors befejezése érdekében megoldási lehetőségeket sikerült kidolgozni, ennek rugalmas és gyors alkalmazása érdekében hatóságunk több nyomozóját vendéglátó/szállodai kapcsolattartóként jelöltük ki.

* Ezúton köszönöm Aszalós György alezredesnek az elkészítésben nyújtott segítségét. 
A szezon kezdete előtt már felmértük a keményebb időszakokat, a nyitóbulikkal tarkított hétvégéket, a nyári hónapokban lebonyolítandó, nagy tömegeket vonzó rendezvényeket, ily módon ezekre idejében felkészülhettünk.

A megyei rendőrfőkapitány döntése alapján a feladatok végrehajtására a Siófoki Rendőrkapitányság a következő vezényelt erőkkel egészült ki:

- Június 1-jétől megyei erö-, eszközátcsoportosítás történt a turisztikailag érintett rendőrkapitányságokra Siófokra, Fonyódra és Marcaliba. A Siófoki Rendőrkapitányságot húsz rendészeti tiszthelyettessel és tíz bünügyes munkatárssal erősítették meg.

- Június 12-től már rendelkezésünkre állt a Készenléti Rendőrség tizenöt fős egysége, majd júliustól teljes létszámban, megközelítőleg hatvan fővel nyújtott támogatást a Készenléti Rendőrség Siófok részére. A legnagyobb létszámú gyalogos járőrszolgálatot és emellett a kerékpáros-szolgálatot adta városunknak a leginkább kiemelt helyeken és időszakokban.

- A teljes szezont lefedve jelen volt a Készenléti Rendőrség helikopteres szolgálata, jelentősen segítve közlekedési és közbiztonsági tevékenységünket, valamint a balatoni vízi rendészeti kapitányság munkáját.

- Július 1. és augusztus 31. között a bünügyi-vizsgálati osztályok huszonnégy fös megerősítést kaptak. A bűnügyi megerősítő erőket elsősorban a Kaposvári Rendőrkapitányság és a Somogy Megyei Rendőr-főkapitányság Bünügyi Igazgatóságának bűnügyes állományából jelölték ki és rendelték át váltásban. Elsősorban a bünügyi helyszínelö tevékenységben és a forrónyomos cselekmények végrehajtásában nyújtottak támogatást. Siófokon július 1. és augusztus 31 . között két bűnügyi helyszíniszemle-bizottság dolgozik 24 órában. Végiggondoltuk, hogy a megerősítő bünügyes munkatársak miben tudnak a leghatékonyabban segíteni, és végül amellett döntöttünk, a legnagyobb tehermentesítést a gyors reagálásokban, az azonnalos feladatok végrehajtásában nyújthatják.

- Ugyancsak július 1. és augusztus 31. között a nap 24 órájában szolgálatban volt egy-egy legalább alosztályvezető beosztású bünügyes és rendészeti tisztparancsnok. Erre a gyors döntéshozatal, az események megfelelő szintü kontrollálása és irányítása, továbbá a felvetődő rendkívüli események, például parancsnoki kivizsgálások végrehajtása érdekében van szükség.

A korábbi években a megerősítő erők nyújtotta segítség több típusát is kipróbáltuk. 
2015-ben is folyamatosan értékeltük a megerősítő erők szükségességét, és a kellő helyzetekre reagálva további rendőröket csoportosítottunk Siófokra a Készenléti Rendőrség, valamint a többi kapitányság állományából.

Nappali időszakban a legtöbb büncselekményt a kimutatásaink szerint a siófoki Beszédes sétányon, a Deák Ferenc sétányon lévő szabad strandokon, valamint a környező utcákban követték el (alkalmi lopások, strandlopások, a parkoló gépkocsik feltörése, illetve gépjármü-eltulajdonítások).

Az éjszakai idöszakban a legtöbb büncselekményt Siófokon az úgynevezett vigalmi negyedben, a Petőfi sétányon és környékén, valamint a nyaralóövezetekben követték el. A jogsértések jellemzően besurranásos, betöréses, zseb-, valamint alkalmi (strand-) lopások, továbbá erőszakos, garázda jellegü cselekmények, illetve kábítószerrel kapcsolatos büncselekmények. Az ilyesfajta büncselekmények megelőzése, kezelése érdekében megerősítettük a folyamatos rendőri jelenlétet a Petőfi sétányon.

A havi ügyforgalmi statisztika adatai szerint a vizsgált időszakban 1197 nyomozáselrendelésre került sor, ez kevesebb a 2014-es adatnál, 1463-nál.

Az elrendelt nyomozásokon belül az elmúlt éveknek megfelelően most is a vagyon elleni büncselekmények dominálnak.

A rablások és kifosztások száma kismértékben növekedett, az előző évi szezonban elrendelt huszonnégyhez képest 2015 nyarán huszonnyolc esetben történt elrendelés (2013-ben harminckét eset történt).

A közrend és közbiztonság elleni büncselekmények körébe tartozó garázdaságok száma csökkent, a 2015-ös szezonban huszonkét esetben kezdeményeztünk eljárást e büncselekmény miatt, ellentétben a 2014-es negyven esettel (2013: 49).

A gépkocsiból történő lopások száma nőtt, 2013-ban 93, 2014-ben 77, 2015-ben 95 eset volt. A gépkocsilopások száma 2014-ben jelentősen csökkent (19-röl 6-ra), 2015-ben pedig ismét emelkedett (16), de a kísérletekkel együtt 25.

A köznyugalmat súlyosan megzavaró büncselekmény a 2015-ös idegenforgalmi szezonban egy történt, a Mártírok útja egyik éttermében egyik szakács életveszélyesen megkéselte a munkatársát. Ezen kívül a területünkhöz tartozó Pusztaszemesen követtek el emberölést. Mindkét ügyben órákon belül elfogták az elkövetőket, akik később előzetes letartóztatásba kerültek. Ellenük a büntetőeljárást a Somogy Megyei Rendőr-főkapitányság Bünügyi Igazgatósága folytatta le. 
A szezon során a kapitányság 99 (2014-ben 75) nyomozást fejezett be bíróság elé állítási javaslattal. Az értékelt időszakban 32 (2014-ben 28) esetben került sor bünügyi őrizetbe vételre.

A bünügyi tapasztalatok feldolgozásánál szembeötlő a nagy tömegeket vonzó rendezvényekhez köthető bünügyi események és nyomozáselrendelések száma. Kiemelendő, hogy kábítószerrel kapcsolatos esemény leggyakrabban a Balaton Sound, illetve a B My Lake idején történt. Ugyancsak ki kell emelni, hogy a legtöbb rablást és garázdaságot a siófoki Petőfi sétányon és a környékén követték el.

Az egyenruhás és civil ruhás erőket mindig a bünügyi fertőzöttségi jellemzőkhöz igazítva irányítottuk a megfelelö időszakokban a megfelelő területekre.

A városi élet dinamikája a következő:

- nagyjából reggel nyolckor a város már csöndes, a mentőszolgálat munkatársai összeszedik a magatehetetlenül ittas személyeket, ellátják, és elszállítják őket a városi kórházba;

- nagyjából tizenegy órától-déltől éledezik minden, késői reggeli után megtelnek a strandok. A siófoki Aranypart és Ezüstpart összefüggő, tizenkét kilométer hosszú strandjain légi felvételek alapján úgy hetven-nyolcvanezer ember strandol egyszerre. Ebben az időszakban aratnak a „strandszarkák”, illetve a strandok előtt megtelő parkolókban a kis késéssel felbukkanó gépkocsifeltörök. Az üresen maradó szálláshelyeken is ez idő tájt történik a legtöbb lopás, betöréses lopás;

- a strandok legkésőbb este hét-nyolc óra körül kiürülnek, a nyaralók vacsorázni mennek, és készülnek az estére, amely Siófokon mindig izgalmas;

- este kilenc, de legkésőbb tíz óra után megtelnek a szórakozóhelyek, a legnagyobb diszkók és a Petőfi sétány. Nyaranta Siófokon öt olyan nagy szórakozóhely üzemel szinte éjjel-nappal, amelyek müködése a zenés-táncos rendezvényekről, helyekről rendelkező 2011/23. számú kormányrendelet hatálya alá tartozik. Ezek telt házasak éjjelente, ahogyan a sétány is, ahol legkevesebb tíz-tizenkét ezer ember zsúfolódik össze a leghúzósabb hét végi éjszakákon;

- péntek és szombat éjjelente éjfél elött a siófoki vasútállomásra begördülnek a „bulivonatok”. Harsány utazóközönségének érkezését és az állomásról, valamint az Indóház utcai szakaszról történő távozását mindig nagy erőkkel kell biztosítani, egyrészt a közlekedés, másrészt a közlekedők biztonsága érdekében. Ez a jellemzően nagyon fiatalokból álló tömeg pár száz, de akár háromezer fős is lehet. A legforróbb nyári hét végi éjszakákon ez a 
„müsorszám” bő félórás, mozgalmas, színes, a leginkább egy futballmeccs utáni stadion kiürítéséhez lehetne hasonlítani;

- a szórakozóhelyeken az esti órákban a zsebelések és az örizetlenül hagyott értéktárgyak (pénztárcák, retikülök, telefonok stb.) eltulajdonítása a legjellemzőbb. És persze egyik-másik szórakozónál felbukkan a drog is, vagy valamilyen, a „pörgést” fokozó ismeretlen, ellenőrizetlen szer;

- megfigyeltük, hogy az alkohol (és egyebek) mértéktelen fogyasztásának, valamint a kifáradás következtében a féktelen szórakozás városszerte úgy hajnali fél három után csap át sokaknál botrányos részegségbe, és ekkor kezdődnek a verekedések, ekkor van a legtöbb hívásunk garázdaságokhoz, testi sértésekhez, motiválatlan rongálásokhoz, gátlástalan törésekhez-zúzásokhoz;

- ekkor bukkannak fel a részegek körül a „virágárus” lányok, leginkább azok körül a külföldiek körül, akiknél már jó előre kifigyelték, hogy vastag a pénztárcájuk. Persze e hölgyek nincsenek ám kíséret nélkül, tisztes közelségből védelmezik őket az „élettársaik”. Ezek a külföldiek (persze vannak hazaiak is) a rablások potenciális áldozatai;

- sokan kapatos állapotban lemennek a sétány mögötti nyitott partszakaszokra, ledobálják a ruháikat és az értékeiket, majd irány az éjszakai fürdőzés! Az éjszakai strandtolvajok csak ezt várják;

- a szórakozók közül sokan lefekszenek a parti fövenyre, a padokra, amikor már mélyen alszanak, a fosztogatók megszabadítják őket az értéktárgyaiktól.

2015 nyarát emlékezetessé tették a fővárosból és máshonnan érkező gépkocsitolvajok: kísérletekkel együtt huszonöt gépjármülopást regisztráltunk, ezekből kiemelkedett az ellopott tizenöt BMW.

A BRFK-val közös akció keretében a helyi rendőrök elfogták a csapat központi alakjait, a házkutatásokon sok bizonyítékot sikerült lefoglalniuk. Kapitányságunk előterjesztésére - mivel az előzetes letartóztatás Be. szerinti feltételei fennálltak - a bíróság a lakhely-elhagyási tilalom mellett döntött. A tolvajok - a kirótt, de súlytalan korlátozó intézkedés szabályait gátlástalanul megszegve - már a következő hétvégén újabb autókat lovasítottak meg.

A kifosztások visszaszorítása, a megelőzés, illetve az elkövetők gyors elfogása érdekében a legzsúfoltabb, legfertőzöttebb öt nyári hétvégén többfös megfigyelő csoportot alkalmaztunk este tíz és hajnali öt óra között. Ez az intézkedés szinte minden hétvégén eredményre vezetett, hiszen négy ügyben négy gyanúsított kapcsán tettünk javaslatot vádemelésre. 
A korábban a régi 7-es út elsősorban gamászapusztai, illetve sóstói szakaszára jellemző és jelentős problémát okozó prostitúciós tevékenység a hatékony rendészeti fellépés következtében jelentősen mérséklődött, most már inkább csak alkalmi jelleggel fordul elő.

A közterületen elkövetett büncselekmények okán (elsősorban a garázdaságok és testi sértések miatt) a turisztikai idényben jelentősen növekszik a rendőri intézkedések száma, a rendészeti értékmérőnek számító személyes szabadságot korlátozó intézkedések közül az elfogások nagyjából harminc százalékkal emelkednek az átlagos időszakhoz képest.

A Petőfi sétányon folyamatosan háromfös rendőri egység mozgott, míg a Porecs téri (nyugati bejárat) és a Tátra utca felöli (keleti bejárat) kapuknál, illetve a Karinthy utcai torkolatnál beavatkozásra kész három-négy fős egységek, általában készenléti rendőrök helyezkedtek el, lehetőség szerint kutyás rendőrrel együtt.

Siófok vigalmi negyede gyakorlatilag egyetlen sétányon helyezkedik el. A mintegy ezerkétszáz-ezerháromszáz méternyi, mindössze negyed négyzetkilométernyi területen hét szálloda és 149 szórakozóhely található. Szinte hihetetlen, de ennek a területnek a kriminalitása döntően meghatározza munkánkat és megítélésünket. E terület biztonságának javításában döntő jelentőségü a helyes rendőr-tömeg arány, azaz az optimális rendőri létszám megtalálása és az elhelyezés helyessége, valamint a gyors reagálás garantálása, az intézkedésbe lépő rendőri erők kiegészítése a felállítási posztokon.

E módon határoztuk meg a szezon minden napján, minden napszakban ha kellett, óráról órára - a közterületi rendőri jelenlétet.

Mindenképpen el kell mondani, hogy a sétányon a jelenleg alkalmazott magánbiztonság gyenge minőségü.

A baleseti helyzetet elemezve megállapítható, hogy az értékelés időszakában a személyi sérüléssel járó közlekedési balesetek száma a 2014-es negyvenegyhez képest ötvenháromra emelkedett, ezen belül a halálos balesetek száma nulláról kettőre, a súlyos sérüléssel járók száma nem változott, ezúttal is tizenhárom, a könnyű sérüléssel végződők száma huszonnyolcról harmincnyolcra emelkedett.

A balesetek okát vizsgálva megállapítható, hogy a balesetek több mint ötven százaléka továbbra is az elsőbbségi jog megsértése és a gyorshajtás miatt következett be.

A balesetet okozó járművezetők közül tízen voltak ittasak, megyei viszonylatban ez az arány meghaladja az átlagot. 
A Somogy Megyei Rendőr-fökapitányságnak érvényes együttműködési megállapodása van a Siófok Közbiztonságáért Polgárőr Egyesülettel.

A siófoki polgárörök az idegenfogalmi szezonban önállóan 28 esetben 265 órában teljesítettek szolgálatot 73 fő bevonásával.

A Siófoki Polgárôr Egyesülettel nyolc alkalommal teljesítettünk közös szolgálatot 108 óra időtartamban. A közös járőrszolgálaton kívül bevontuk őket fokozott ellenőrzésekbe is, továbbá az augusztus 20-i rendezvénybiztosításba. A fokozott ellenőrzés során alkalmaztuk a polgárőrség kezelésében lévő Mátrix rendszámfelismerö rendszert is.

A polgárőr egyesület vezetője minden hónap elején eljuttatta a rendőrkapitányságra a szolgálattervezetét, mindez lényegesen megkönnyíti a közös szolgálatszervezést.

Más polgárőr egyesületekkel is szoros az együttmüködés, a nyári idegenforgalmi szezonban a közbiztonság fenntartásában minden egyesület jelentős szerepet vállalt.

Itt kell megemlíteni, hogy a Siófoki Polgárör Egyesület bizony elbírna még több tagot is, a városban jelenleg elég passzívak vagy bátortalanok a segítők. Mindezt Túrós András egykori országos fökapitány, az Országos Polgárör Szövetség jelenlegi elnöke is felrótta a 2015-ös balatonföldvári polgárörrendezvényen.

Ennek több oka van. Siófokon létezik városőrség, és a város vezetése elsősorban e szervezet munkáját finanszírozza. A polgárör tevékenység önkéntes és nonprofit.

Azt is hallottam már, hogy az ebben az időszakban tapasztalható erőszakos garázda jellegü cselekmény és agresszív elkövetők bátortalanná teszik és eltérítik azokat, akik az önkéntes tevékenységre jelentkeznének.

A siófoki városőrség vezetöjével a kapcsolattartás példaértékü és folyamatos volt. Több esetben kaptunk jelzést tőlük gyanús gépjárművekről, személyekröl. A szolgálatszervezéskor előre tervezetten, szükség esetén ad hoc jelleggel közös szolgálatot láttunk el a városőrökkel.

Nagy előrelépés volt a térfigyelő kamerák monitorjainak kapitányságra való áttelepítése a városőrség irodájából. A figyelésük, kezelésük, illetve egyegy konkrét cselekménnyel kapcsolatos felvétel archiválása, mentése eleinte nem ment zökkenőmentesen, de a városőrség minden hívásunkra soron kívül személyes segítséget nyújtott.

A kamerák segítségével sikerült megcáfolni több büncselekmény megtörténtét, illetve a felvételek sikeresen hozzájárultak több ténylegesen elkövetett büncselekmény (lopás, garázdaság) felderítéséhez, bizonyításához. 
Az idegenforgalmi szezonban a tervezetten elrendelt fokozott ellenőrzésekkor, de eseti jelleggel is együttmüködtünk a járási hivatal, az adóhatóság, Nemzeti Fogyasztóvédelmi Hatóság, az ÁNTSZ, valamint a polgármesteri hivatal munkatársaival. A társhatóságokkal való együttműködés kiemelkedően jól müködött például a zenés-táncos rendezvények, szórakozóhelyek közös ellenőrzéseinél.

\section{Bünmegelőzési munkánk, a diákcentrumok tevékenysége}

Az elkövetett büncselekmények további csökkentéséhez elengedhetetlen volt a prevenciós tevékenység.

Bünmegelőzési feladatainkat, kötelezettségeinket az alaptörvény rögzíti.

Magyarország Alaptörvényének 46. cikk (1) bekezdése mondja ki, hogy „A rendörség alapvetö feladata a büncselekmények megakadályozása, felderitése..."

2015-ben a bünmegelőzési centrum július 6. és augusztus 24. között üzemelt Siófokon. A program keretében tevékenykedő hetvenhat diák a kaposvári Eötvös Loránd Müszaki Szakközépiskolából és a dombóvári Apáczai Csere János Szakközépiskola és Kollégiumból érkezett hét turnusban.

A bünügyi osztály erre kijelölt bünmegelőzési előadójának vezetésével, heti turnusonként az aktuális bűnügyi-közbiztonsági helyzetnek megfelelően végezték feladataikat. Klasszikus bünmegelőzési tevékenységet folytattak magyar és idegen nyelvü szórólapok terjesztésével, részt vettek strandlopásokra szervezett figyelésekben, valamint Bünmegelözés feliratú pólóban gyalog és kerékpárral demonstrációs jelleggel tartózkodtak a strandokon és a bünügyileg kiemelt területeken.

Az előbbieken túl sok esetben segítettek állampolgárok jelzése alapján eltünt személyek, föként gyermekek felkutatásában.

Előfordult, hogy észlelték a strandolni érkezők nyitva felejtett vagy lehúzott ablakkal hátrahagyott gépjármüvét (két esetben még az indítókulcsot is benne hagyták), megvárták a tulajdonost, és felhívták a figyelmét, milyen könnyen büncselekmény áldozatává válhatott volna.

A diákok több esetben lopási szándékkal érkező, „portyázó” személyeket riasztottak el az orrizetlenül hagyott értékek (kerékpárok, telefonok, pénztárcák, indítókulcsok stb.) közeléből, valamint a rendőrök az ő jelzésük alapján fogtak el egy bünelkövetőt is. 
A diákok valódi partnerek voltak. A közvetlen irányítás, szakmai útmutatás alapján nagyon lelkesen végezték megelőző és már-már felderítő feladataikat. Igaz a tétel, hogy a gyerekek roppant gyorsan tanulnak, mert nem kellett sokat magyarázni, megértették a feladatot, és remekül teljesítettek.

E program méltán volt sikeres, sok volt az érdeklődő, így például szeptemberben tanulmányúton volt városunkban a székesfehérvári Ciszterci Szent István Gimnázium egyik osztálya, amely a nyári szezonban felvetődő bünügyi-rendészeti problémák kezelése iránt érdeklődve ellátogatott a Siófoki Rendőrkapitányságra. A Somogy Megyei Rendőr-főkapitányság bünmegelőzési osztályának vezetőjével, $d r$. Jávorszkiné $d r$. Molnár Magdolna rendör alezredessel közösen tájékoztattuk a diákokat, majd a diákok és a kísérö tanár is az iránt érdeklödtek, hogyan kapcsolódhatnának be a projektbe.

Az eredmények, valamint a fiatalokra gyakorolt kiváló nevelő hatása miatt is érdemes gondolkodni a program bővítésén.

\section{Összegzés}

A Balaton Sound öt napja alatt csak a siófoki rendőröknek kétezer-ötszáz túlórájuk keletkezett százszázalékos tiszthelyettesi kategóriában számolva. A másik kétezer-ötszázat a hozzánk érkező, minket erősítő Somogy megyei kollégák használták fel.

Az összképhez hozzátartozik, hogy azok helyett, akik a Soundon teljesítettek szolgálatot, az otthon maradóknak túlszolgálniuk kellett, hogy az alapfeladatok teljesíthetők legyenek.

A tomboló nyár és a rekordméretü turizmus ellenére összetett és a mindenkori helyzethez igazítottan folyamatosan változtatott rendészeti intézkedéseink nyomán a 2014-es évhez képest jelentősen csökkent a büncselekmények száma.

2012-ben a Siófoki Rendőrkapitányság nyomozáseredményessége még tizenegy-tizenkét százalékon állt, 2015. nyár közepén ez a szám elérte az ötvenhét százalékot.

Ha azt veszem alapul, amim van, és nem azzal foglalkozom, ami nincs, továbbá tudomásul véve, hogy tapasztalt - hely- és személyismerettel felvértezett -, képzett munkaerőt nem tudunk csatasorba állítani, az eredményesség további emelése szempontjából - a jelenlegi humánerőforrás-kapacitások mellett - a legnagyobb valószínüséggel a büncselekmények számának további drasztikus csökkentése hozhat áttörést. 
Persze nagyon sokat kell még tennünk, nekünk, rendőröknek és a civileknek egyaránt, hogy megváltoztassuk a Siófokot „a bủn városaként” bemutató véleményt.

Például javasoltuk

- a közvilágítás javítását meghatározott területeken, városrészeken;

- a térfigyelőkamera-rendszer további bővítését, a meglévő kamerák minőségire cserélését;

- a problémás, kriminálisan fertőzött szórakozóhelyek nyitva tartásának szabályozását;

- a siófoki városőrség és mellette a polgárőrség további erősítését, fejlesztését;

- a nyári bünmegelőzési diákcentrum további támogatását, esetleges bővítését.

Külön megemlítem, hogy a Petőfi sétányon lévő vigalmi negyed müködésének szabályozása és az ott nyújtott szórakoztatás, vendéglátás európai szintüre emelése ügyében stratégiai időszak következik.

2015 végén lejár az előző kilencéves koncesszió, azaz az önkormányzat ha a képviselö-testület úgy dönt - újraköti a müködtetési szerződéseket.

Okos, kompromisszumos gondolkodással, a vendéglátók képviselőivel való konstruktív együttmüködéssel olyan feltételek teremthetők, amelyek a 2016-os nyári szezonban sokkal nagyobb biztonságot garantálnak a Siófokra látogató vendégeknek, turistáknak ugyanúgy, mint a szállásadóknak, vendéglátósoknak is. Ennek érdekében már megkezdtük a munkánkat, és örömmel számolhatok be arról, hogy a vendéglátásban tevékenykedő szereplők részéről nyitottságot és aktív partnerséget tapasztalunk. Így - közös gondolkodással, összefogással - valóban nagy eséllyel számolhatunk azzal, hogy városunk tovább tisztul a nemkívánatos kriminális jellemzőktől, jelenségektől. Sokat kell gondolkodni, egyeztetni, szervezni, időt, energiát és anyagiakat ráfordítani mind a nagybetüs RENDÉSZET, mind a civil résztvevők oldaláról, egyre nagyobb mértékben bevonva a magánbiztonsági szektort.

Meggyőződésem, hogy az egyre bővülö, erősödő összefogás városunk rendjének minőségi javulásához vezet. 